\title{
THE EUROPEAN SCHOOL OF ANTENNAS: RESULTS AND PERSPECTIVES
}

S. Maci ${ }^{(1)}$, B. Lindmark ${ }^{(2)}$, A. Freni ${ }^{(3)}$, O. Breinbjerg ${ }^{(4)}$, A. Räisänen ${ }^{(5)}$, J-M. Laheurte ${ }^{(6)}$, K. Mahdjoubi ${ }^{(7)}$ F. Frezza ${ }^{(8)}$ G. Vecchi ${ }^{(9)}$, L. Jofre ${ }^{(10)}$, M. Sierra Perez ${ }^{(11)}$, M. Ferrando ${ }^{(12)}$, P. S. Kildal ${ }^{(13)}$, A. Skrivervik ${ }^{(14)}$, G. Gerini ${ }^{(15)}$ J. L. Dubard ${ }^{(16)}$, B. Casali ${ }^{(17)}$, D. Manteuffel ${ }^{(18)}$, O. Bucci ${ }^{(19)}$, W. Wiesbeck $^{(20)}$, M. Mazanek ${ }^{(21)}$, Z. Sipus ${ }^{(22)}$, P. Hall ${ }^{(23)}$, C. Ibars ${ }^{(24)}$.

Universita' degli Studi di Siena, Italy, (2) Kungliga Tekniska Hoegskolan, Sweden (3) Universita' degli Studi di Firenze, Italy (4) Danmarks Tekniske Universitet, Denmark (5) Helsinki University of Technology, Finland, (6) Universite de Marnes La Vallee, France, (7) Institut National des Sciences Appliquees de Rennes, France (8) Universita' degli Studi di Roma "La Sapienza", Italy, (9) Politecnico di Torino, Italy, (10) Universitat Politecnica de Catalunya, Spain, (11) Universidad Politecnica de Madrid, Spain, (12) Universidad Politecnica de Valencia, Spain, (13) Chalmers University of Technology, Sweden, (14) Ecole Polytechnique Federale de Lausanne, Switzerland, (15) Netherlands Organisation for Applied Scientific Research, The Netherland, (16) Université de Nice Sophia Antipolis, France, (17) Ingegneria dei Sistemi, Italy, (18) IMST Gmbh, Germany, (19) Unıversita' deglı Studı di Napolı "Federıco II", Italy, (20) Unıversity of Karlsruhe, Germany, (21), Czech Technical University, Czech Republic, (22) University of Zagreb, Croatia (23) University of Birmingham, United Kingdom, (24) Centre Tecnologic de Telecomunicacions de Catalunya, Spain.

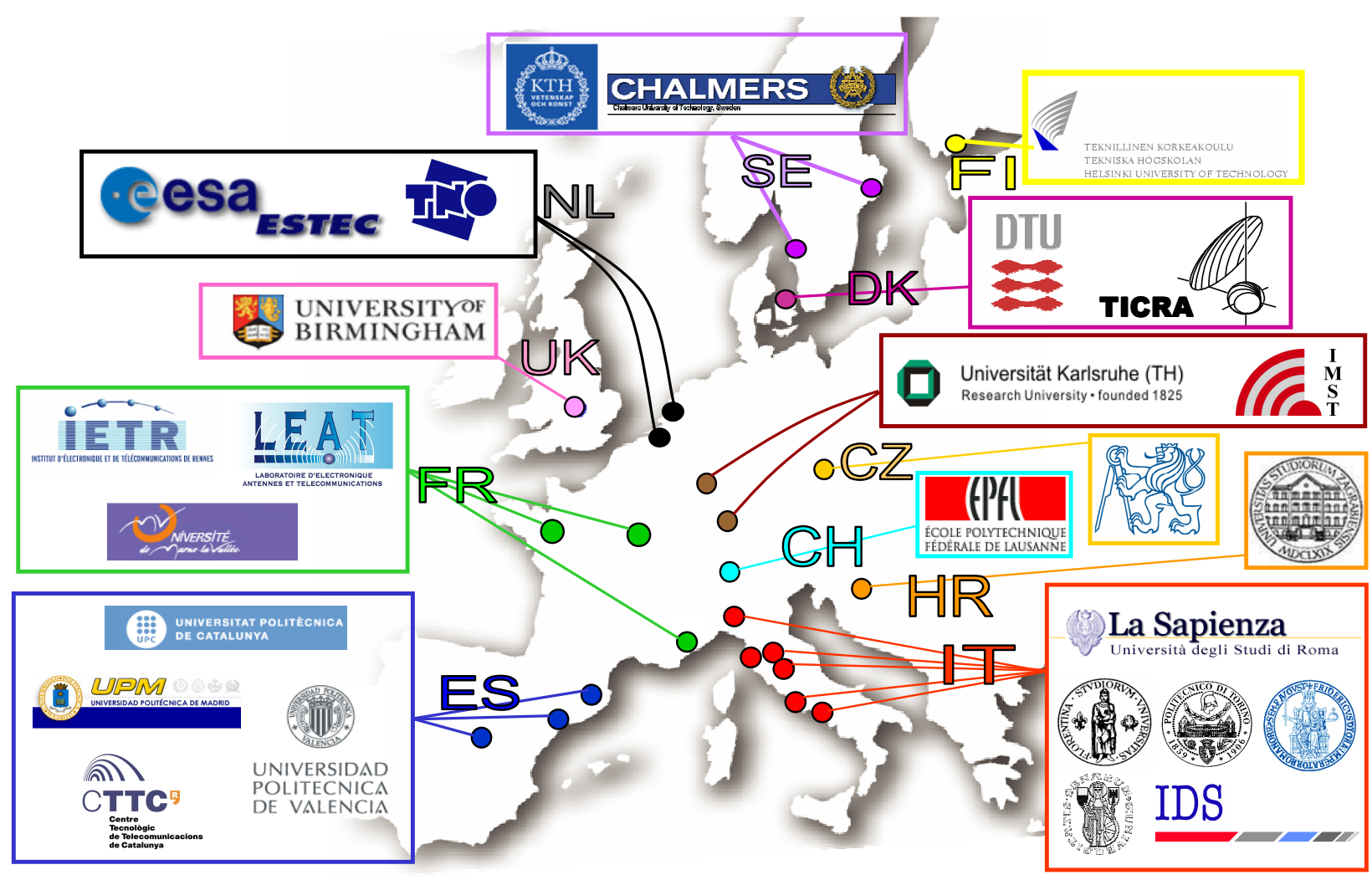

Fig. 1 Geographical distribution of the ESoA group 


\section{Abstract}

The European School of Antennas (ESoA) is a new model of geographically-distributed school that has the objective to reinforce the European training and research in antennas and relevant applications. This paper presents the objective and perspectives of ESoA and the results obtained in 2006 and the first part of 2007 in terms of flow of students and teachers.

\section{Introduction}

The European School of Antennas (ESoA) was founded in 2004 by a group of institutions in the framework of the FP6 Network of Excellence "ACE - Antenna Centre of Excellence" [1], and it is presently financed by ACE and by a Marie Curie Action (MCA) project. The general objectives of the School are: 1. reinforcing the European excellence in wireless systems with emphasis on antenna components; 2. creating an effective advanced formative offer at international level to complete individual $\mathrm{PhD}$ curricula; 3 . increasing the ties in wireless research and development between Universities and Industries on a European scale; 4. facilitating the interchange of ideas among early-stage researchers and trainers as well as among young researchers, thus increasing the future mobility and synergy. The ESoA courses are distributed in the most accredited European research centres on antennas and wireless systems.

\begin{tabular}{|l|l|c|}
\hline \multicolumn{1}{|c|}{ Institution } & Acronym & \\
\hline Univ. degli Studi di Siena & UNISI & IT \\
\hline Univ. degli Studi di Firenze & UNIFI & IT \\
\hline Kungliga Tekniska Högskolan & KTH & SE \\
\hline Danmarks Tekniske Universitet & DTU & DK \\
\hline Helsinki Univ. of Tecnology & TKK & FI \\
\hline Univ. De Marnes La Vallee & UMLV & FR \\
\hline Inst. National des Scie. Appl. de Rennes & IETR & FR \\
\hline Univ. degli Studi di Roma "La Sapienza" & SAPIENZA & IT \\
\hline Politecnico di Torino & POLITO & IT \\
\hline Univ. Politecnica de Catalunya & UPC & ES \\
\hline Univ. Politecnica de Madrid & UPM & ES \\
\hline Univ. Politecnica de Valencia & UPV & ES \\
\hline Chalmers Tekniska Högskola & CHALMERS & SE \\
\hline Ecole Polytechnique Fed. de Lausanne & EPFL & CH \\
\hline Netherlands Org. for Appl. Scientific Res. & TNO & NL \\
\hline Univ. de Nice Sophia Antipolis & UNSA & FR \\
\hline IMST GmbH & IMST & D \\
\hline Ingegneria dei Sistemi & IDS & IT \\
\hline Univ. of Naple "Federico II" & UNINA & IT \\
\hline Univ. of Karlsrhue & UNIKARL & D \\
\hline Czech Technical University & CTU & RO \\
\hline Univ. of Zagreb & UNIZAG & HR \\
\hline Univ. of Birmingham & UNIBHAM & UK \\
\hline Centre Tecnologic de Telecom. de Catalunya & CTTC & ES \\
\hline & & \\
\hline
\end{tabular}

Table I : Institutions belonging to ESoA

\section{ESoA Institutions and course coordinators}

The ESoA initiative started in 2004 from a group of institutions composed by Universities and industrial research centres of 12 different European countries belonging to ACE [1]. Presently, the group has been enlarged to the 24 institutions grouped in Fig. 1 and listed in Table I. The 24 institutions have signed a Memorandum of Understanding in order to implement and develop ESoA with the intention to: extend and encourage the participation to ESoA to Parties external to the group; lay down the basis to prolong the ESoA activity even beyond the expire date of the EU project; establish common rules for the attribution and recognition of doctorate credits, establish an ESoA board, and setting its competences concerned with the structuring, organization and management of the courses; state the "excellence of teaching" as a fundamental principle aiming the ESoA activity. The board is composed by various prominent personalities of the Antennas and Propagation community (Figure 2).
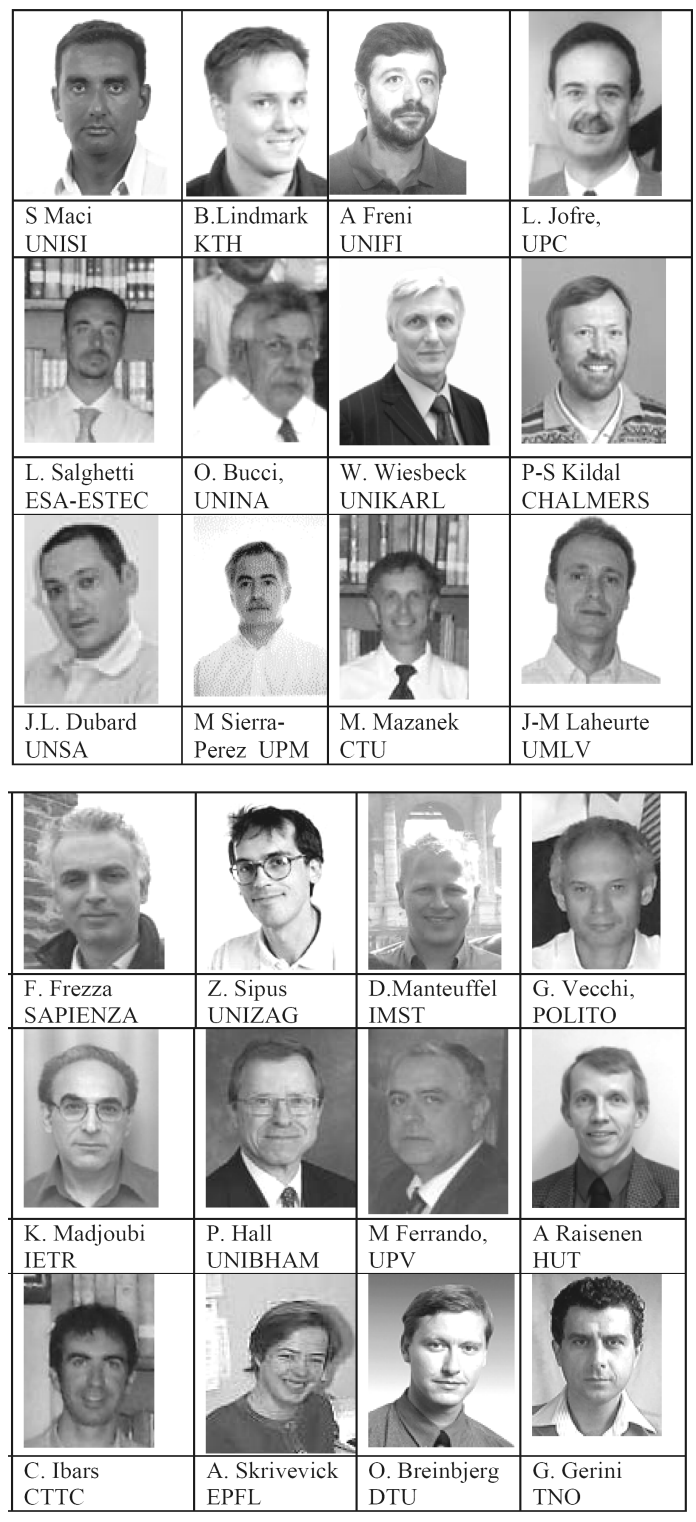

Fig. 2 ESoA Board 


\section{Format of the courses}

Each course extends for one week; this format allows the students to organize their mobility without sacrificing their research activity at home, and leaving open the possibility to extend their stay in the host institution - assumed excellent in the specific area - to complete their research training. The courses take 5 days, with possible home-assignments for extra-credits. The typical format of one course consists on 5 hours of lectures in the morning, and 3-4 hours of other activities in the afternoon. These activities will be concerned with exercises, reading of key papers on topical subjects, laboratory experiments (when available), panel discussions, and student presentations. The total structure thus consists on about 25 hours of lectures and 15-20 hours of other activities. The lectures will be provided in part by people from the host Universities, but predominantly by speakers from the other institutions of the group. The courses also include the participation of key-note speakers from industries and Universities external to the group. Each course, which foresees a written assessment test, provides to the students from 3 to 4 ECTS credits, depending on the quantity of additional home assignments.

\section{Content of the courses}

Fig. 3a presents an overall view of the ESoA courses, and Fig. 3b shows the map of the courses for 2007 and 2008. The position of the courses in Fig. 3a is related to their content. The diagram presents a vertical axis that ranges from analysis to design and a horizontal axis ranging from theory to wireless systems through applications. Broadly speaking, the diagram could be divided in two parts from a bisector diagonal from the upper-left to the lower-right corner. The courses positioned in the lower part (analysis and theory) are more devoted to students interested in basic research (like academic $\mathrm{PhD}$ students) and the ones in the upper part (design, applications and systems) are more appealing for industrial $\mathrm{PhD}$ students and post-graduate students oriented toward the industrial applications. Small overlapping of topics can occur and serves to guarantee a uniform continuity to this unitary framework. The courses of theory and analysis (lower/left part of the diagram) have the main objective to give to the $\mathrm{PhD}$ students the advanced concept on the analysis method for antenna and electromagnetic scattering problems and the basic and advanced knowledge for developing software tools for antenna modelling. These courses synthesize all the modern computational techniques based on integral equations (method of moments), and on differential equations (finite difference time domain and finite element methods), as well as on the high-frequency and hybrid techniques based on asymptotic methods. The basic methodologies are completed by a course about antenna synthesis and optimization and by two courses about measurements techniques, which provide the techniques from microwave to submillimeter wave frequencies. The courses in the upper/right part of the diagram are more concerned with antenna design and wireless systems.

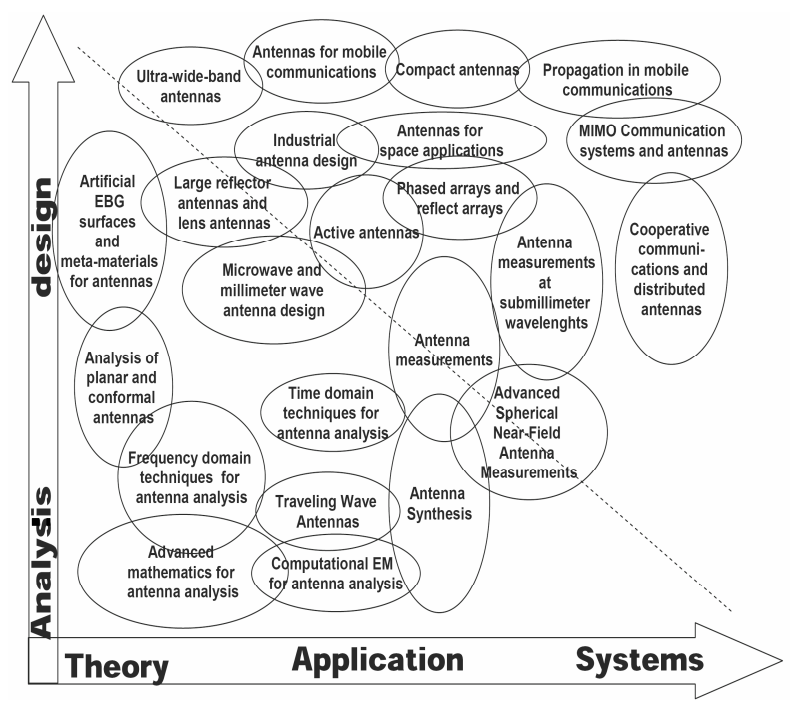

(a)

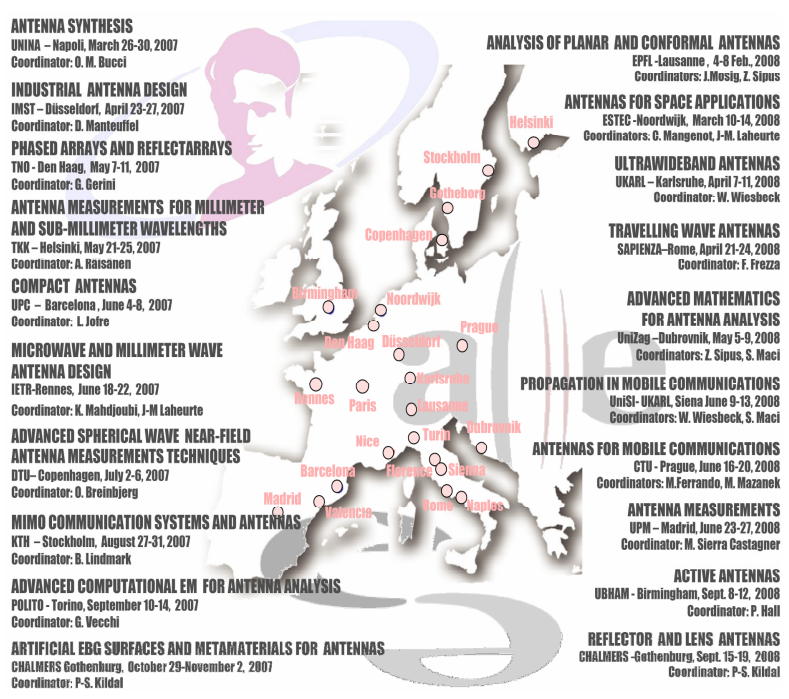

(b)

Figure 3: (a) ESoA diagram, (b) ESoA courses in 2007 (left-hand side) and 2008 (right-hand side)

These course provide to the students design methods inside the application framework (upper/right corner) of radio wireless fixed and mobile communications, radar, remote sensing, aeronautics and space, transport, security, with special emphasis on a) System for mobile communications and propagation channels in urban environment b) MIMO systems c) Cooperative communications d) Space systems of communications. The courses on antenna design (upper/left corner) advanced issues on the classical antenna typologies like reflector antennas and feed-horns, lens antennas, phased array antennas, planar and conformal antennas, traveling wave antennas. Furthermore, they include the emerging antenna technology as a matter of 
research with special emphasis on i) Active and integrated antennas, ii) Multibeam and adaptive antennas iii) Antenna with digital beamforming, iv) Ultrawideband antennas v) EBG and metamaterial antennas, vi) Compact antennas vii) Fractal antennas.

\section{Web support}

The school is supported by a dedicated web site [2], which is a special section of the "Virtual Center of Excellence" (VCE) [3], the official web site of ACE. The relevant items are: a) Centralizing and facilitating as much as possible the on line registration of the students; b) Organizing and making publicity and dissemination actions; c) Collecting the electronic material to support the school (namely: i Electronic forms of the speaker presentations, iiHomework, iii- Evaluation forms, iv- Notes and reference to textbooks, v- Output of the exams); d) Collecting the progress report ad final documentation e) Updating the list of the grants for the students; f) Showing the availability of research positions in the EM research area within Europe; g) Creating and updating of the Virtual Antenna Laboratory (VALab) with the purpose to render available the free-ware educational software or software developed by the partners [4].

\section{Participation of students}

A summary of data relevant to 2006 is given in this section. Table II summarizes the course participation of students in 2006: 243 students have participated to ESoA with an average of 22 student per course, with a maximum of 27 students (course of Lausanne) and a minimum of 14 students (course of Nice). The average of students per course was 22 in 2005, too. Table II a summarizes the 2007 data available till September: 187 students have participated to ESoA with an average of 21 student per course, a maximum of 33 students (course of Stockholm), and a minimum number of 11 students (course of Rennes). A good indicator of the success of ESoA is the International mobility index (IMI), defined as the ratio between the number of student not belonging to the host country over the total number of student per course. The average IMI of 2005 was $50 \%$. The IMI of 2006 is detailed in the last row of Table II. The average IMI in 2006 has been $61 \%$, with a maximum of $83 \%$ (Barcelona) and a minimum of $31 \%$ (Prague). The partial average IMI in 2007 has been 75\%, with a maximum of $100 \%$ (Den Haag) and a minimum of $45 \%$ (Naples). The last column of Table II (a) indicate the percentage provenance of the students: Italy (20\% in 2006 and $23 \%$ in 2007) and Spain (19\% in 2006 and 25\% in 2007) had the larger participation. Other important indicators are: i) \% of students belonging to ACE Universities over the total number of students; ii) \% of students belonging to ACE Industries over the total number of students, iii) $\%$ of students belonging to non-ACE Universities over the total number of students, iv) $\%$ of students belonging to non-ACE Industry over the total number of students The diagram in Fig. 4 compares these parameters in the years 2005, 2006 and 2007.

\section{Participation of teachers}

The results relevant to the teachers are reported in Table IIIa (2006) and Table III b (2007). The average number of teachers (including assistant and lecturers) is 8.7 per course. Spain (24\%) and Italy (15\%) had the large participations of teachers in 2006. Presently, in 2007 the average number of teachers (including assistant and lecturers) is 6 per course. Finland (24\%) and France (20\%) had the large participations of teachers till July 2007. An IMI for the teachers (defined as the percentage of teachers per course not belonging to the host country over the total) is also calculated in the last row of the Table. The average IMI was $60 \%, 54 \%$ and $30 \%$ in $2005,2006,2007$, respectively. The maximum IMI was $86 \%$ in 2006 (Lausanne) and $80 \%$ in 2007 (Den Haag).

\section{Concluding remarks}

The European School of Antennas constitutes a new geographically-distributed post-graduate school model, successfully experimented in 2005 and 2006. The school will continue till the end of 2009 under financial support of a Marie Curie project.

\section{Acknowledgments}

The Authors thank the European Union for financial support to ESoA in the framework of the FP6 projects ACE and Marie Curie Action in reference to [1] and [5], respectively.

\section{References}

[1] "Network of Excellence" contract FP6-IST 508009 and FP6-IST 026957, Antenna Center ofd Excellence (ACE). [2] Virtual Center of Excellence (VCE) section of EsoA: htpp://www.antennasvce.org/education/ESoA/view [3] (VCE), ACE web site: htpp://www.antennasvce.org [4] VCE section VALab: web site htpp//valab.det.unifi.it /new/valab

[5] "Marie Curie Conferences and Training Courses" Contract n.MSCF-CT-2006-046042 (ESoA) 


\begin{tabular}{|c|c|c|c|c|c|c|c|c|c|c|c|c|}
\hline \begin{tabular}{|l} 
Course \\
Provenience
\end{tabular} & $\begin{array}{l}\text { Spain / } \\
\text { Barce }\end{array}$ & $\begin{array}{l}\text { UK I } \\
\text { B irm in }\end{array}$ & $\begin{array}{l}\text { Croatia } / \\
\text { Dubrov. }\end{array}$ & $\begin{array}{l}\text { Nether. } 1 \\
\text { Noordw. }\end{array}$ & $\begin{array}{l}\text { Germa. I } \\
\text { Karlsruh }\end{array}$ & $\begin{array}{l}\text { Spain } 1 \\
\text { Madrid }\end{array}$ & $\begin{array}{l}\text { Czech / } \\
\text { Prague }\end{array}$ & $\begin{array}{l}\text { Italy I } \\
\text { Siena }\end{array}$ & $\begin{array}{l}\text { Italy I } \\
\text { Floren. }\end{array}$ & \begin{tabular}{|l|}
$\begin{array}{l}\text { Switzer. } \\
\text { Lausa. }\end{array}$ \\
\end{tabular} & $\begin{array}{l}\text { France / } \\
\text { Nice }\end{array}$ & Total \\
\hline Spain & 4 & 2 & 1 & 2 & 5 & 16 & & 4 & 5 & 6 & 1 & 46 \\
\hline \begin{tabular}{|l|} 
Italy \\
\end{tabular} & & & 7 & 11 & 3 & 1 & 1 & 5 & 11 & 4 & 5 & 48 \\
\hline UK & & 14 & 2 & & & 2 & 1 & & & & & 19 \\
\hline Sweden & 2 & 4 & 1 & & 2 & 3 & & 3 & & 2 & 1 & 18 \\
\hline \begin{tabular}{|l} 
Netherlands \\
\end{tabular} & & & 1 & 9 & 2 & & & & 3 & & & 15 \\
\hline France & 4 & 1 & & & 1 & 1 & 2 & 3 & & 2 & 3 & 17 \\
\hline Czech Repu. & & & & & & & 11 & & & & & 11 \\
\hline Germany & 1 & & & 1 & 4 & 1 & & 2 & 1 & & 2 & 12 \\
\hline Finland & 5 & & & & & & & 2 & & 2 & & 9 \\
\hline Switzerland & & & & & 2 & & & & & 7 & & 9 \\
\hline Croatia & & 1 & 5 & & & & & & 1 & 2 & & 9 \\
\hline Greece & 4 & & & & & 1 & & 1 & & & & 6 \\
\hline Belgium & & & 3 & 1 & & & & & & & & 4 \\
\hline USA & & 1 & & & 1 & 1 & & & & 1 & & 4 \\
\hline Portugal & 3 & & & & 2 & & & & & & & 5 \\
\hline Serbia & & & & & & & 1 & 1 & & 1 & & 3 \\
\hline Poland & 1 & & & & & & & 1 & & & & 2 \\
\hline Argentina & & & & 1 & & & & & & & & 1 \\
\hline Saudi Arabia & & & & & & & & & & & 1 & 1 \\
\hline Russia & & & & 1 & & & & & & & & \\
\hline India & & & & & & & & & & & 1 & 1 \\
\hline Ukraine & & & & & & & & & 1 & & & 1 \\
\hline Denmark & & & & & & & & & 1 & & & 1 \\
\hline TOTAL (AVE 22) & 24 & 23 & 20 & 26 & 22 & 26 & 16 & 22 & 23 & 27 & 14 & 243 \\
\hline FOREIGN \% (AVE 61\%) & $83 \%$ & $39 \%$ & $75 \%$ & $65 \%$ & $82 \%$ & $38 \%$ & $31 \%$ & $77 \%$ & $52 \%$ & $47 \%$ & $78 \%$ & \\
\hline
\end{tabular}

(a)

\begin{tabular}{|c|c|c|c|c|c|c|c|c|c|c|}
\hline Provenience & $\begin{array}{l}\text { Italy } / \\
\text { Naples }\end{array}$ & $\begin{array}{l}\text { Germa. } \\
\text { Dusser. }\end{array}$ & $\begin{array}{l}\text { Nether. } \\
\text { Den Haag }\end{array}$ & $\begin{array}{l}\text { Finland. } \\
\text { Helsinky }\end{array}$ & $\begin{array}{l}\text { Spain } 1 \\
\text { Barce. }\end{array}$ & $\begin{array}{l}\text { France } \\
\text { Rennes }\end{array}$ & $\begin{array}{l}\text { Denmar/C } \\
\text { openha. }\end{array}$ & $\begin{array}{l}\text { Sweden/ } \\
\text { Stock }\end{array}$ & \begin{tabular}{|l|} 
Italy/ \\
Torino
\end{tabular} & Total \\
\hline Spain & 4 & 3 & 6 & 5 & ten & 2 & 4 & \begin{tabular}{|ll} 
I & 7 \\
\end{tabular} & vinus & 46 \\
\hline Italy & 12 & 1 & 6 & 1 & 4 & 1 & 3 & 4 & 11 & 43 \\
\hline UK & & 2 & & & 1 & & & 2 & . & 5 \\
\hline Sweden & & 2 & & & 3 & 1 & & 7 & 1 & 14 \\
\hline Netherlands & & & & & & 2 & & & 2 & 4 \\
\hline France & 1 & 4 & & & 2 & 4 & 1 & 2 & 1 & 15 \\
\hline Czech Repu. & & & & 1 & & & & 1 & 3 & 5 \\
\hline Germany & & 3 & & & 4 & & & 1 & 1 & 9 \\
\hline Finland & 1 & 2 & 1 & 4 & & 1 & & 3 & & 12 \\
\hline Switzerland & & & & & & & 1 & & & 1 \\
\hline Croatia & & 1 & & & & & 1 & 1 & & 3 \\
\hline Greece & & 1 & 1 & & 1 & & & 4 & & 7 \\
\hline Serbia & & & & & & & & & 2 & 2 \\
\hline Belgium & 1 & & & & 1 & & & & 1 & 3 \\
\hline USA & & & & 2 & & & & & & 2 \\
\hline Portugal & & 1 & & & 3 & & & & & 4 \\
\hline Poland & & 1 & & & & & & & & 1 \\
\hline Argentina & & & & 1 & & & & & & 1 \\
\hline Russia & 1 & & & & & & & & & 1 \\
\hline China & & & & 1 & & & & & & 1 \\
\hline Turkey & 1 & & & & & & & & & 1 \\
\hline Iraq & 1 & & & 1 & & & & & & 2 \\
\hline Canada & & 1 & & & & & & 1 & & 2 \\
\hline South A frica & & & & & 1 & & & & & 1 \\
\hline Denmark & & & & & & & 2 & & & 2 \\
\hline TOTAL (AVE 21) & 22 & 22 & 14 & 16 & 27 & 11 & 12 & 33 & 30 & 187 \\
\hline FOREIGN \% (AVE $75 \%)$ & $45 \%$ & $91 \%$ & $100 \%$ & $75 \%$ & $74 \%$ & $67 \%$ & $83 \%$ & $79 \%$ & $63 \%$ & \\
\hline
\end{tabular}

(b)

Table II Statistics for the students. Column refers to the location of the courses and rows to the nationality of the participating students. (a) 2006, (b) 2007 (till September, one course missing) 


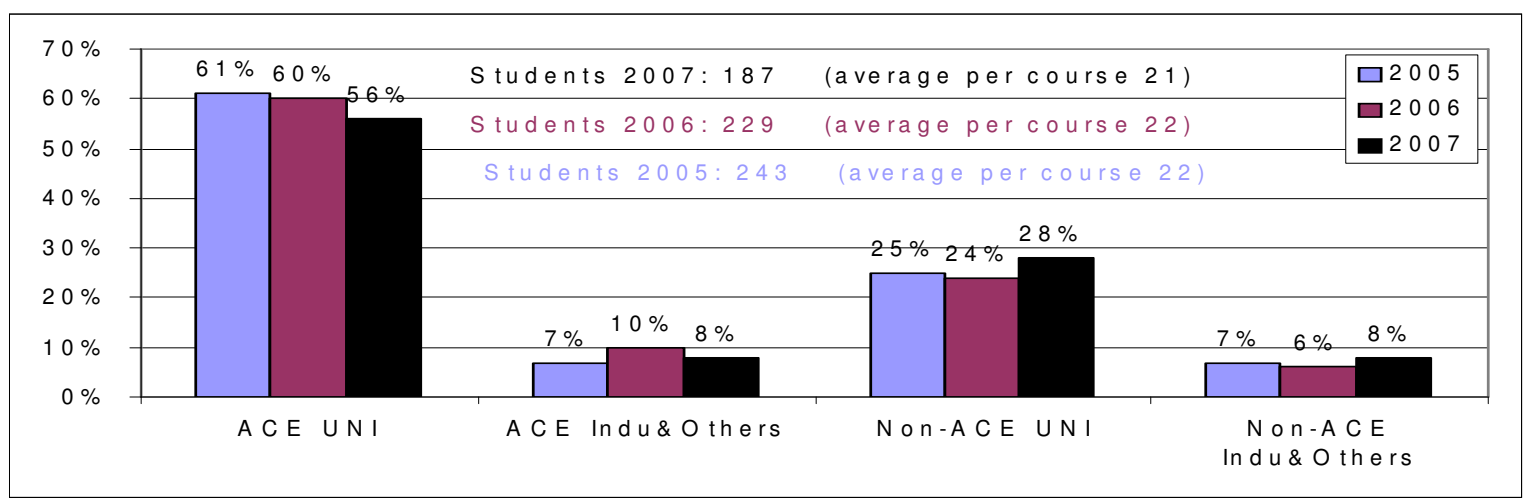

Figure 4. Percentage of students per categories

\begin{tabular}{|c|c|c|c|c|c|c|c|c|c|c|c|c|}
\hline Provenience & $\begin{array}{l}\text { Spain / } \\
\text { Barce }\end{array}$ & $\begin{array}{l}\text { U K I } \\
\text { B irm in }\end{array}$ & $\begin{array}{l}\text { Croatia / } \\
\text { Dubrov. }\end{array}$ & $\begin{array}{l}\text { Nether. I } \\
\text { Noordw. }\end{array}$ & $\begin{array}{l}\text { Germa. I } \\
\text { Karlsruh }\end{array}$ & $\begin{array}{l}\text { Spain / } \\
\text { M adrid }\end{array}$ & $\begin{array}{l}\text { Czech / } \\
\text { Prague }\end{array}$ & $\begin{array}{l}\text { Italy I } \\
\text { Siena }\end{array}$ & $\begin{array}{l}\text { Italy I } \\
\text { Floren. } \\
\end{array}$ & \begin{tabular}{|l} 
Switzer. \\
Lausa.
\end{tabular} & $\begin{array}{l}\text { France / } \\
\text { Nice }\end{array}$ & TOTAL \\
\hline Spain & 3 & & & & 2 & 10 & 4 & & 1 & & & 20 \\
\hline Italy & & & 3 & 2 & & & 3 & 2 & 2 & & & 12 \\
\hline Germany & & & & 1 & 5 & & 1 & 3 & & & 2 & 12 \\
\hline Sweden & 2 & & & & & 2 & & & & 3 & 1 & 8 \\
\hline $\mathrm{UK}$ & & 5 & & & & & & & & & 2 & 7 \\
\hline Croatia & & 1 & 2 & & & & & & 1 & 1 & & 5 \\
\hline France & 1 & 1 & & & & 2 & & & 1 & & 5 & 10 \\
\hline Czech Rep. & & & & & & & 3 & & & & & 3 \\
\hline Switzerland & & & & & & & & & 2 & 1 & & 3 \\
\hline Belgium & & & & & & & & & 1 & 1 & & $\overline{2}$ \\
\hline Finland & & & & & & 1 & & & & & & $\overline{1}$ \\
\hline Serbia & & & & & & & & & & 1 & & 1 \\
\hline TOTAL (AVE 9) & 6 & 7 & 5 & 13 & 8 & 16 & 11 & 5 & 9 & 7 & 10 & 97 \\
\hline IMI\% (AVE 55\%) & $50 \%$ & $28 \%$ & $60 \%$ & $31 \%$ & $37 \%$ & $60 \%$ & $72 \%$ & $60 \%$ & $77 \%$ & $85 \%$ & $50 \%$ & \\
\hline
\end{tabular}

(a)

\begin{tabular}{|c|c|c|c|c|c|c|c|c|c|c|}
\hline $\bar{Z}$ & $\begin{array}{l}\text { Italy I } \\
\text { Naples }\end{array}$ & $\begin{array}{l}\text { Germa. I } \\
\text { Dusser. }\end{array}$ & \begin{tabular}{|l|} 
Nether. / Den \\
Haag
\end{tabular} & $\begin{array}{l}\text { Finland. I } \\
\text { Helsinky }\end{array}$ & $\begin{array}{l}\text { Spain I } \\
\text { Barce. }\end{array}$ & $\begin{array}{l}\text { France / } \\
\text { Rennes }\end{array}$ & $\begin{array}{l}\text { Denmark } \\
\text { /Copenha. }\end{array}$ & $\begin{array}{l}\text { Sweden/ } \\
\text { Stock }\end{array}$ & \begin{tabular}{|l|} 
Italy/ \\
Torino
\end{tabular} & TOT \\
\hline Spain & & & & & 1 & & & 1 & 1 & 3 \\
\hline Italy & 5 & & 1 & & & & & & 3 & 9 \\
\hline Sweden & & & 1 & & & & & 3 & & 4 \\
\hline Netherlands & 1 & 1 & 1 & & & & & & & 3 \\
\hline France & 1 & 1 & 1 & & & 6 & & & 1 & 10 \\
\hline Germany & & 2 & & & & & & & & 2 \\
\hline Finland & & & & 8 & & & & 4 & & 12 \\
\hline USA & 1 & & & & & & & & & 1 \\
\hline Denmark & & & 1 & 1 & & & 4 & & & 6 \\
\hline TOTAL ( AVE 6 ) & 8 & 4 & 5 & 9 & 1 & 6 & 4 & 8 & 5 & 50 \\
\hline $\begin{array}{l}\text { FOREIGN \% } \\
\text { (AVE 31\%) }\end{array}$ & $37 \%$ & $50 \%$ & $80 \%$ & $11 \%$ & $0 \%$ & $0 \%$ & $0 \%$ & $63 \%$ & $40 \%$ & \\
\hline
\end{tabular}

(b)

Table III: Statistics for the teachers. Column refers to the location of the courses and rows to the nationality of the participating Teachers. (a) 2006, (b) 2007(till September, one course missing). 